\title{
The influence of tourist evaluative factors on tourist behavioral intention: the mediating role of tourist satisfaction
}

\author{
ELMER HAFIIZH FERNALDI ${ }^{1}$ and I MADE SUKRESNA ${ }^{1}$, \\ ${ }^{1}$ Department of Management, Faculty of Ecomonics and Business, Universitas Diponegoro, Indonesia
}

\begin{tabular}{ll}
\hline Abstract & This study examines the effect of tourist evaluative factors, specifically service quality and \\
tourist experience on tourist satisfaction and its further influence on revisit intention and \\
intention to recommend. Service quality and tourist experience serve as independent \\
variables, while revisit intention and recommend intention are posited as dependent \\
variables, with satisfaction acts as the intervening variable. Data analysis using Structural \\
Equation Modeling (SEM) of 186 tourist visiting Umbul Sidomukti, Semarang, Central \\
Java, Indonesia, finds that both revisit intention and intention to recommend could be \\
increased through the improvement of service quality and tourist satisfaction.
\end{tabular}

Keywords

service quality, tourist experience, tourist satisfaction, revisit intention, intention to recommend.

\section{INTRODUCTION}

Since decentralization policy was effective in 2001, every region in Indonesia either district or city has continued to develop its region even faster by maximizing its territorial potencies, among which are natural resources. Indonesian's abundance of natural resources have been utilized by local government even at district level to attract the attention of many people as tourist destinations. One of the famous tourist destinations is located in Semarang district, Central Java, known as Umbul Sidomukti.

Umbul Sidomukti is a tourist destination that is quite familiar to the people around Semarang, Salatiga, and Solo. Although it is popular; however, during 2009 - 2015, the number of visitors decreased from 85,224 in 2009 to 53,278 in 2015. This was inversely proportional to other artificial attractions such as Langen Tirto, Kartika kopeng, or Kapoeng Kopi Banaran. In 2009, the number of tourists visiting Umbul Sidomukti was the highest compared to the other three tourist spots, but in 2015, Umbul Sidomukti was the fewest, as the number of tourist visiting Tirto was 62,377 , Kartika Wisata Kopeng 104.052, and Kampoeng Kopi Banaran was 117,328 people.
Umbul Sidomukti, a remote but peaceful area, is located in Sidomukti Village subdistrict Bandungan, Semarang regency. Consequently, electricity supply is inadequate causing some activities and new tourist development should be limited. In addition, some tourism reviews promote negative comments against Umbul Sidomukti, among which are lack of services. The decline in tourist visitation to Umbul Sidomukti may be stemmed from the lack of services quality to visitors causing lack of intention to behave positive travel in the future. Therefore, it warrants an appropriate strategy to increase the number of tourist; a strategy covering two aspects of service quality and tourists experience. According to the backgroud described above, this study aims to examine the effect of service quality and tourist experience on tourists satisfaction. Furthermore, the effect of tourists satisfaction on tourist future behavior is assessed.

\section{HYPOTHESES DEVELOPMENT}

\section{Service quality and tourist satisfaction}

Service quality and tourist satisfaction are constructs representing comparison between expectations and perceived performance. 
Satisfaction refers to the assessment of services deliverance, whilst service quality refers to how services should be provided (Zeithaml et al., 1988). In addition, the underlying differences are satisfaction belongs to a broader concept, whilst service quality focuses on the dimension of service. Kozak and Remmington (2000) argue that assessment of service quality determines consumers satisfaction, and since it comes from their assessment of perceived quality, they will determine whether they are satisfied or not as a whole.

H1: Service quality positively influences tourist satisfaction

\section{Tourist experience and tourist satisfaction}

Currently, business people are not just selling their products/services, but also instilling experience consumers can feel when buying or consuming them. Cole and Illum (2006) identify the quality of experience has a significant relationship with satisfaction. Similarly, Chen and Chen (2010) state that satisfaction is closely related to the tourist experiences, as when tourists get experiences at a tourist spot, they would collect the experiences and express their satisfaction or dissatisfaction.

H2: Tourist experience positively influences tourist satisfaction.

\section{Tourist satisfaction and tourist behavioral intention}

Costomer satisfaction refers to the discrepancy between expectations and perceived performance (disconfirmation) (Oliver, 1980). A higher expectation over performance/service leads to dissatisfaction, vice versa. Chen et at. (2011) argue that a significant satisfaction influences tourists' intention to behave. When tourists feel satisfied, they will be loyal to the tourist destination and might likely to revisit and recommend it (Chen and Phou, 2013).

H3: Tourist satisfaction positively influences revisit intention.

H4: Tourist satisfaction positively influences intention to recommend.

\section{Service quality and tourist behavioral intention}

In tourism industry, tourist perception of service quality is very important in determining their attitude to the next trip (Ahmed in Kim, et at., 2012). Zabkar et al. (2010) suggest that a tourist spot offering fascinations integrated with the tourists' needs could deliver a fit between satisfaction and the tourists' behavioral intention. In addition, studies on service quality find that service quality influences behavioral interests such as interests of revisiting and of recommending (Kim et al., 2012; Lee et al., 2007; Zeithaml et al, 1996).

H5: Service quality positively influences revisit intention.

H6: Service quality positively influences intention to recommend

\section{Tourist experience and tourist behavioral intention}

Chang et al (2014) argue the importance for managers of tourist attractions to be more attentive in understanding tourists experiences when they visit the sites. Provided tourist feels positive experiences, their interest of revisiting likely occurs. This is in line with the finding of Cole and Illum (2006) that when tourists' psychological state closely relates to their experienced benefits, it would influence their future travel behavior.

H7: Tourist experience positively influences revisit intention

H8: Tourist experience positively influences intention to recommend

\section{METHODS}

\section{Data collection}

The population in this study are visitors or tourists who visited Umbul Sidomukti. Data are collected by distributing 186 questionnaires to respondents using nonprobability sampling (purposive sampling) technique. Of the 186 data collected, the majority of the tourists were student $(69 \%)$, among which were male (59\%). The respondents sample were mostly aged 21-25 years $(52 \%)$, and most of the respondents earn monthly income $\leq$ Rp 2,000,000 (67\%). 
Table 1.

Confirmatory Factor Analysis

\begin{tabular}{|c|c|c|c|}
\hline $\begin{array}{l}\text { Cons } \\
\text { truct }\end{array}$ & Indicator & Loading & T-Value \\
\hline \multicolumn{4}{|c|}{ Service Quality| CR: 0.917; AVE: 0.614; a: 0.916} \\
\hline $\mathrm{X} 1$ & Good behavior and attitude shown & .813 & 14.87 \\
\hline $\mathrm{X} 2$ & Employee competence & .853 & 13.98 \\
\hline X3 & Willingness to respond to employees & .816 & 13.07 \\
\hline X4 & Attractive tourist attraction & .742 & 11.36 \\
\hline X5 & Comfortable facilities & .817 & 12.91 \\
\hline X6 & Secure facility & .723 & 10.93 \\
\hline X7 & Easy to access transportation & .711 & 10.70 \\
\hline \multicolumn{4}{|c|}{ Tourist Experience| CR: 0.897; AVE: 0.686; a: 0.897} \\
\hline X8 & Feel happy/excited & .787 & 13.61 \\
\hline X9 & Feel comfortable/relaxed & .819 & 14.83 \\
\hline $\mathrm{X} 10$ & Feel want to know and try other facilities & .864 & 13.61 \\
\hline $\mathrm{X} 11$ & Feeling surprised/amazed & .843 & 12.79 \\
\hline \multicolumn{4}{|c|}{ Satisfaction | CR: 0.912; AVE: 0.776; a: 0.914} \\
\hline $\mathrm{Y} 1$ & Positive comparative appraisal of the tourist spots & .873 & 17.37 \\
\hline Y2 & Meet the tourists expectations & .890 & 17.36 \\
\hline Y3 & Satisfied with the tourist attractions & .880 & 16.85 \\
\hline \multicolumn{4}{|c|}{ Revisit Intention| CR: 0.908; AVE: 0.769; a: 0.907} \\
\hline Y4 & Intend to revisit & .917 & 16.01 \\
\hline Y5 & Be the prioritize place for holidays & .817 & 16.02 \\
\hline Y6 & Finding latest information about the sites & .894 & 19.94 \\
\hline \multicolumn{4}{|c|}{ Intention to Recommend | CR: 0.928; AVE: 0.812; a: 0.927} \\
\hline Y7 & Willing to share the experiences & .899 & 17.92 \\
\hline Y8 & Promote positive things & .879 & 17.91 \\
\hline Y9 & Recommend as tourist destination & .925 & 19.16 \\
\hline
\end{tabular}

\section{Measurement}

Service quality was measured using 7 items developed by Chen et al. (2011), while tourist experience was measured using 4 items developed by Kao et al. (2008) and Otto and Ritchie (1996). Tourist satisfaction was measured using 3 items developed by Cronin et al. (2000) and Yoon and Uysal (2005) while revisit intention was measured using 3 items developed by Hutchinson et al. (2009), Kim et al. (2009), and Putu Agung et al. (2015). Meanwhile, intention to recommend was measured using 3 items developed by Hutchinson et al. (2009).

\section{RESULTS}

\section{Confirmatory factor analysis}

The first step to perform SEM was to conduct confirmatory analysis (Ghozali, 2014). Confirmatory analysis tests the validity of each indicator against its latent variables and the possibility of each construct to form a structural equation. The detailed results of the confirmatory analysis is described in Table 1.
Table 1 shows the overall analysis of confirmatory factor of the measurement model of this study. Confirmatory factor analysis was conducted to measure the validity and reliability of the key constructs used in the research variables. The minimum construct reliability test showed that the result should be 0.7 to achieve a reliable or consistent result (Ghozali, 2014). The CR value of each variable ranged from 0.77 to 0.93. These results showed that the constructs used in the research model could be stated to have a consistent level of goodness. In addition, the value of Average Variance Extracted also showed higher results from the limit value of 0.5 (Ghozali, 2014). The AVE values in all variables ranging from 0.61 to 0.81 showed good and consistent value to the construct used.

Meanwhile, in Convergent Validity assessment, all construct items having factor loading values, ideally minimum 0.5 but more than 0.7 will be better (Ghozali, 2014), are acceptable and significant. Table 1 shows that all items have passed the validity test with the smallest value on item X7 which is 0.711 . In addition, the value of Critical Ratio (T-value) also is significant in $\mathrm{p}>0.01$. 
Table 2.

Goodness-of-Fit

\begin{tabular}{|c|c|c|c|}
\hline $\begin{array}{l}\text { Goodness- } \\
\text { of-Fit Index }\end{array}$ & Cut-Off Value & Result & Criterion \\
\hline Chi - Square & $\begin{array}{l}\text { Expected to be smaller } \\
\text { that Chi-Square table, } \\
\text { with sig. } \alpha=0.01 \text {, and df } \\
=161 \text {, so } \chi{ }^{2} \text { tabel }= \\
205.6600\end{array}$ & 204.469 & Fit \\
\hline Probability & $\geq 0.01$ & 0.012 & Fit \\
\hline CMIN/DF & $\leq 2,00$ or 3,00 & 1.270 & Fit \\
\hline GFI & $\geq 0.90$ & 0.903 & Fit \\
\hline AGFI & $\geq 0.90$ & 0.873 & Marginal \\
\hline CFI & $\geq 0.90$ & 0.985 & Fit \\
\hline TLI & $\geq 0.90$ & 0.988 & Fit \\
\hline RMSEA & $\leq 0.08$ & 0.038 & Fit \\
\hline
\end{tabular}

Table 3

Regression Weights

\begin{tabular}{cccccccc}
\hline \multicolumn{2}{c}{ Relationships } & Estimate & S.E. & C.R. & P & Result \\
\hline Satisfaction & $\leftarrow$ & Service Quality & .353 & .092 & 3.856 & $* * *$ & Accepted \\
Satisfaction & $\leftarrow$ & Tourist Experience & .726 & .091 & 8.015 & $\star \star *$ & Accepted \\
Revisit Intention & $\leftarrow$ & Satisfaction & .450 & .154 & 2.924 & .003 & Accepted \\
Intention to Recommend & $\leftarrow$ & Satisfaction & .518 & .176 & 2.942 & .003 & Accepted \\
Revisit Intention & $\leftarrow$ & Tourist Experience & .419 & .092 & 4.560 & $\star * *$ & Accepted \\
Intention to Recommend & $\leftarrow$ & Service Quality & .059 & .149 & .395 & .693 & Rejected \\
Revisit Intention & $\leftarrow$ & Service Quality & .293 & .133 & 2.210 & .027 & Accepted \\
Intention to Recommend & $\leftarrow$ & Tourist Experience & .409 & .100 & 4.076 & $* * *$ & Accepted \\
\hline
\end{tabular}

\section{Hypotheses testing}

To test the hypotheses, SEM using AMOS program ver. 22.0 was employed to examine the model's goodness-of-fit and the developed hypotheses. The results are shown in Table 2 and Table 3.

Table 2 shows the model is fit with the data used in the study. This is indicated by the chi-square value of 204.469 corresponding to the expected small value of cut off chi-square value, the value of significance probability $\geq 0.01$ is 0.012 , and the value of CMIN/DF is 1.270. In addition, the values of GFI, CFI, TLI, and RMSEA corresponded to the cut-off value despite the AGFI value is only marginal.

We also conducted some test of the SEM assumptions. The normality test shows that some of values of c.r univariate were above 2.58 and some of the values of c.r multivariate were below 2.58. Therefore, the data in this study were normally distributed multivariate, but not normally distributed univariate.
The result of the outlier test shows that the value of the mahalanobis distance was below $37.56(D F=20$; Prob $=0.01)$, which become benchmark of the mahalanobis distance value in this research. Thus, there was no outlier data in this research.

The result of the multicollinearity test shows that the value of the determinant of sample covariance matrix was 2.734 , far from zero. Thus, there was no multicollinearity or singularities problem on data used in this research.

The result of the residual test shows that the value of the standardized residual covariance was below 2.58; therefore, there was no error value in the sample and population.

The result of the hypotheses test of critical ratios (cr) and the probability ( $p$ ) depicted in Table 3 shows that of the eight proposed hypotheses, seven were accepted because their $\mathrm{cr}$ values are above 2.56 and $\mathrm{p}$ values are below 0.01 ; whereas, one hypothesis is rejected because it has cr values of below 2.56 and $p$ values of above 0.01 . The accepted hypotheses were the 
influence of service quality to satisfaction and to revisit intention, then the tourists experience to satisfaction, intention to recommend and to revisiting intention, and the influence of satisfaction on the interest to recommend and revisit intention. The hypotheses were in line with previous research. The rejected hypothesis is the influence of service quality on the interest to recommend.

\section{DISCUSSION}

Increased tourist satisfaction can be directly influenced by the service quality and tourist experience. This was in line with the finding of Chen et al. (2011) on the service quality and Chen and Chen (2010) on the tourist experience. Between the two variables, the service quality (0.73) was more dominant in terms of satisfaction. Thus, tourist spot of Umbul Sidomukti Semarang need to pay attention and improve the quality of service through indicators presented in this study.

Increased revisit intention is influenced by the service quality, tourist experience, and tourist satisfaction. This result was consistent with the finding of Chen et al. (2011) on satisfaction, Kim et al. (2012) on service quality, and Chen and Chen (2010) on the tourist experience. Of the three, the one having the greatest influence on revisit intention to Umbul Sidomukti was tourist satisfaction. The satisfaction (0.45) had a larger loading factor when compared to the service quality $(0.29)$ as well as the quality of the tourist experience (0.42). This is logically accepted, as satisfaction is an overall tourist judgment of all aspects they value and feel. Thus, it is very important that Umbul Sidomukti satisfy the tourists by improving service and friendly atmospheres environment; so that, the tourists' experiences become more valuable.

Improved intention to recommend is influenced by satisfaction and tourist experiences. Among other variables, satisfaction had the greatest effect (0.52). This result was consistent with the finding of Chen et al. (2011) on satisfaction, and Cole and Illum (2006) on a tourist experiences. Thus, the company can strive to strengthen interest in recommending Umbul Sidomukti. If the satisfaction of tourists at the spot is very high, this can be a binding encouragement for tourists to recommend the site as a vacation/recreation destination.

The variable of service quality does not have a direct influence on the intention to recommend. The results of this study were in line with research results of Hutchinson et al. (2009) that the quality of service does not have a direct influence on the tourist intention to recommend in the future. This condition is a reasonable fact; due to the tourists' assessment given are not high but not low as well, or normal. However, through open questions, some negative answers about the quality of services in Umbul Sidomukti were stated such as the cleanliness of the bathroom and access to transportation to Umbul Sidomukti. Therefore, this becomes one of the causes of the absence of significant relationship between service qualities with intention to recommend.

Figure 1.

Results of the structural model

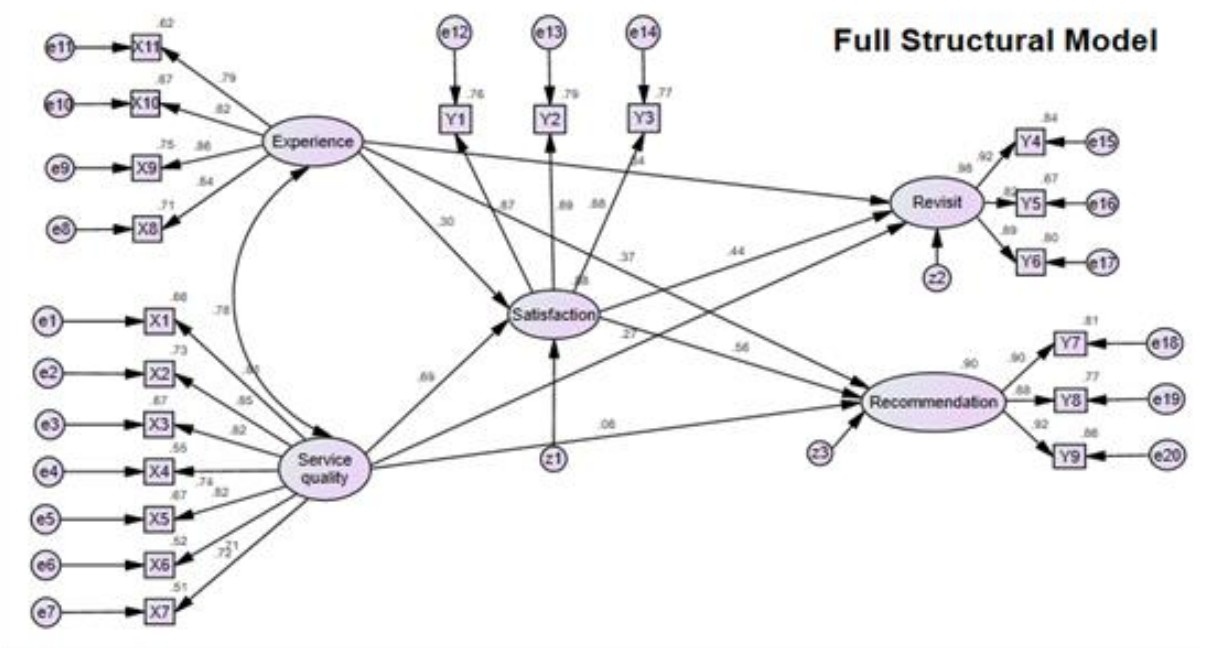




\section{Managerial implication}

The result shows that the respondents consider the service quality of Umbul Sidomukti were well in some aspects. Even so, there are some that need to be improved, such as accessibility and service. The accessibility especially main roads that are still rocky and public transportation. For the service, especially at the place to eat, there are some reviews saying that the service is slow. For that reasons, in the future the services need to be improved and to be more responsive. Then, the management of Umbul Sidomukti needs create a tourist database; so that, management can provide better quality of service.

From the results we can also suggest that the local government in cooperation with PT. Panorama Agro Sidomukti should improve the transportation access to Umbul Sidomukti to be accessible. We also suggest to local communities to maintain the sustainability of the village Sidomukti and its environment to continue to make the area as a tourist destination.

Panorama Agro Sidomukti should be responsible for improving the service quality in Umbul sidomukti, particularly improving the accessibility and service.

Umbul Sidomukti also needs to maintain the beauty of the place and keep all facilities well maintained, especially access roads, parking lot, and adrenaline rides that require special attention. Then, improvement and development of facilities that can attract tourists to be more amazed/surprised at the facilities offered

\section{Research limitations}

The sample in the population used was concentrated in respondents aged between 18-25 years. Another limitation was respondents asked to answer the questionnaire were still concentrated in some spots of Umbul Sidomukti and were not yet able to touch tourists as a whole. The other was in the analysis of full model of SEM, there were some criteria of Goodness of Fit which was marginal i.e. AGFI.

\section{Suggestions for future research}

Future research needs to have a pre-survey conducted to determine the motivation and reviews about the experience of tourists in traveling to Umbul Sidomukti and to provide an overview of the variables to be studied.

Future research need to add indicators to strengthen independent and dependent variables, because this study only focuses on two indicators. The indicator suggested is the attributes of tourism products (Hapsari, Lubis, Widiartanto, 2014); so that, further research can further explain about tourism products of Umbul Sidomukti.

Further research might compare among tourist objects to identify the most sought tourist destination by including reasons for arrival according to the category of tourist spots; so that, the attribute variable of tourism products are in line with research conducted.

\section{REFERENCES}

Badan Pusat Statistik, 2014, Kabupaten Semarang dalam Angka tahun 2014, Kabupaten Semarang

Badan Pusat Statistik, 2015, Jawa Tengah dalam Angka tahun 2015, Jawa Tengah

Badan Pusat Statistik, 2015, Kabupaten Semarang dalam Angka tahun 2015, Kabupaten Semarang

Badan Pusat Statistik, 2016, Kabupaten Semarang dalam Angka tahun 2016, Kabupaten Semarang

Chang, L.-L., F. Backman, K., \& Chih Huang, Y. (2014). Creative tourism: a preliminary examination of creative tourists' motivation, experience, perceived value and revisit intention. International Journal of Culture, Tourism and Hospitality Research, 8(4), 401-419. http://doi.org/10.1108/IJCTHR-04-20140032

Chen, C., \& Chen, F. (2010). Experience quality, perceived value, satisfaction and behavioral intentions for heritage tourists. Tourism Management, 31(1), 29-35. doi:10.1016/j.tourman.2009.02.008

Chen, C. F., \& Phou, S. (2013). A closer look at destination: Image, personality, relationship and loyalty. Tourism Management, 36, 269-278.

Chen, C. M., Lee, H. T., Chen, S. H., \& Huang, T. H. (2011). Tourist behavioural intentions in relation to service quality and customer satisfaction in Kinmen National Park, Taiwan. International Journal of Tourism Research, 13(5), 416-432.

Cole, S. T. (2006). Examining the mediating role of festival visitors' satisfaction in the relationship between service quality and behavioral intentions. Journal of Vacation Marketing, 12(2), 160-173.

Cronin, J. J., Brady, M. K., \& Hult, G. T. M. (2000). Assessing the effects of quality, value, and customer satisfaction on consumer 
behavioral intentions in service environments. Journal of Retailing, 76(2), 193-218. http://doi.org/10.1016/S00224359(00)00028-2

Ghozali, Imam. 2014. Model Persamaan Struktural Konsep Dan Aplikasi Dengan Program Amos 22.0. 6 ed. Semarang: Badan Penerbit Universitas Diponegoro.

Hapsari, N. R. (2014). Pengaruh Atribut Produk Wisata dan Electronic Word of Mouth (eWOM) Terhadap Keputusan Berkunjung Pada Objek Wisata Umbul Sidomukti Kabupaten Semarang, (24). Jurnal IImu Administrasi Bisnis

http://megapolitan.kompas.com/read/2009/11/22/1 8250182/pengembangan.umbul.sidomukt i.terganjal.pasokan.listrik accessed on 29-11-2016

Hutchinson, J., Lai, F., \& Wang, Y. (2009). Understanding the relationships of quality, value, equity, satisfaction, and behavioral intentions among golf travelers. Tourism Management, 30(2), 298-308.

Kertajaya, H., \& Nirwandar, S. (2013). Tourism Marketing 3.0: Turning Tourist to Advocate. Jakarta: Kompas Gramedia

Kim, S. H., Holland, S., Han, H. S. (2012). A Structural Model for Examining how Destination Image, Perceived Value, and Service Quality Affect Destination Loyalty: a Case Study of Orlando. International Journal of Tourism Research,

Kim, T., Kim, W. G., \& Kim, H. B. (2009). The effects of perceived justice on recovery satisfaction, trust, word-of-mouth, and revisit intention in upscale hotels. Tourism Management, 30(1), 51-62. http://doi.org/10.1016/j.tourman.2008.04. 003

Kozak, M., \& Rimmington, M. (2000). Tourist Satisfaction with Mallorca, Spain, as an Off-Season Holiday Destination. Journal of Travel Research, 38(3), 260-269.

Lee, Y. S., Petrick, J. F., Crompton, J. (2007). The Roles of Quality and Intermediary
Constructs in Determining Festival Attendees , Behavioral Intention, 45(May), 402-412.

Oliver, R. L. (1980). A Cognitive Model of the Antecedents and Consequences of Satisfaction Decisions. Journal of Marketing Research, 17(4), 460 - 469

Otto, J. E., \& Ritchie, J. R. B. (1996). The service experience in tourism. Tourism Management, 17(3), 165-174.

Parasuraman, A., Zeithaml, V. A., \& Berry, L. L. (1985). A conceptual Model Service Its Quality and Implications for Future. Journal of Marketing, 49(4), 41-50.

Parasuraman, A, Zeithaml, V. A, \& Berry, L. L. (1988). SERVQUAL: A Multiple-Item scale for Measuring Consumer Perceptions of Service Quality. Journal of Retailing

Putu Agung, A. A., Tamba, M., \& Suryawathy, I. G. A. (2015). The Influence of Tourism Attributes and Promotion on the Consumer Image and Decision to Revisit Kintamani Ecotourism, Bangli Regency. Management and Organizational Studies, 2(3), 72-79.

Yoon, Y., \& Uysal, M. (2005). An examination of the effects of motivation and satisfaction on destination loyalty: A structural model. Tourism Management, 26(1), 45-56.

Zabkar, V., Brencic, M. M., \& Dmitrovic, T. (2010). Modelling perceived quality, visitor satisfaction and behavioural intentions at the destination level, 31, 537-546.

Zeithaml, V. A., Berry, L., \& Parasuraman, A. (1996). Behavioral Consequences of Service Quality. Journal of Marketing, 60(2), 31-46. 